\title{
CIVIL PROCEDURE: FINAL JUDGMENT RULE: STATE COURT VENUE DETERMINATION CONSIDERED FINAL FOR PURPOSES OF APPEAL
}

T HE FINAI judgment rule requiring that judgments, decrees, and decisions of state and federal district courts be "final" in order to be reviewable has long been an important requisite to the exercise of federal appellate jurisdiction. ${ }^{1}$ Recently the Supreme Court apparently relaxed its rigid insistence on finality and reviewed a state court venue judgment heretofore considered interlocutory. In Mercantile Nat'l Bank v. Langdeau, ${ }^{2}$ the Court held it had jurisdiction to review a judgment of the Texas Supreme Court, affirming, prior to trial on the merits, a trial court determination that venue in the case was properly laid. The Court did so on the ground that the judgment determined a substantial claim, pertaining to a separate and independent matter, anterior to the merits, the immediate determination of which would serve the policy underlying the requirement of finality by avoiding long and complex litigation which might be of no avail if consideration of the claim were postponed until the conclusion of the proceedings. ${ }^{3}$

The case involved an action against two national banks and other parties for conspiracy to defraud. Each bank filed a plea of privilege, claiming the right, under a federal statute, to be sued only in the county in which it was located. The plaintiff, on the other hand, relying upon a state venue statute, filed suit in a county in which neither of the banks was located. The trial court dismissed the banks' motions for change of venue and the Texas Supreme

1 "Final judgments or decrees rendered by the highest court of a State in which a decision could be had, may be reviewed by the Supreme Court as follows: . . (2) By appeal, where is drawn in question the validity of a statute of any state on the ground of its being repugnant to the Constitution, treaties or laws of the United States, and the decision is in favor of its validity." 28 U.S.C. $\$ 1257$ (1958).

"The courts of appeals sball have jurisdiction of appeals from all final decisions of the district courts of the United States . . . except where a direct review may be had in the Supreme Court." (Emphasis added.) 28 U.S.C. \$ 1291 (1958).

The rule was incorporated in the original Judiciary Act of 1789 , ch. $20, \$ \S 21,22$, 25, I Stat. 73. See generally, 1 Barron \& Holdzoff, Federal Practice and Procedure $\S 57$ (1960, Supp. 1962); 3A BarRoN \& HoltzofF, op. cit. supra § 1552; 6 MOORE, FEDERAL Practice 154.11-.14 (2d ed. 1953, Supp. 1962) [hereinafter cited as Moore]; Note, Appealability in the Federal Courts, 75 HARv. L. Rev. 351 (1961).

2371 U.S. 555 (1963).

' $I d$. at 558. 
Court affirmed. Because of the conflict between the state and federal statutes, the defendant banks appealed to the Supreme Court. ${ }^{4}$ The Court was thus faced with the issue whether the state court judgment satisfied the requirement of finality.

As noted in Republic Natural Gas Co. v. Oklahoma, ${ }^{5}$ considerations relating to the smooth functioning of the judicial system underlie the finality requirement. First, there exists the policy against premature adjudication of constitutional questions. Second, there is the fact that the interlocutory question sought to be appealed from may be mooted by trial on the merits. ${ }^{\circ}$ Third, the trial may generate additional federal questions which make relevant the Court's policy against fragmentary review. ${ }^{7}$ In this regard, the final judgment rule has been referred to as "essential to the achievement of a 'just, speedy, and inexpensive determination of every action," "s necessary in order to avoid "the delay in reaching trial finality which ensue[s] when piecemeal appeals are permitted." 9 Moreover, the finality requirement guarantees that potential conflict between state and federal courts will be kept to a minimum and thus "derives added force when the jurisdiction of the Court is invoked to upset the decision of a State court."10

\footnotetext{
tThe appeal was brought pursuant to the provisions of 28 U.S.C. $\S 1257$ (2) (1958), note 1 supra.

5334 U.S. 62, 69-71 (1948). The Supreme Court here refused to review the decision of a state supreme court which affirmed an interlocutory order directing that a producer of natural gas take it "ratably" from the well of another producer by connecting their pipelines. The Court refused to review the order in spite of the fact that the state court had interpreted the order as directing immediate compliance or a shutting down of the producer's wells.

' Id. at 71. It can be seen, for example, that if in the National Bank case the appellants won on the merits, they certainly would not appeal the venue decision.

7 Ibid. See generally 6 Moore 9 54.11; Note, 75 HARv. L. REv. 351-52 (1961).

${ }^{8}$ Brown Shoe Co. v. United States, 370 U.S. 294, 306 (1962) (divesture order reserving final ruling held final).

- Paliaga v. Luckenbach S.S. Co., 301 F.2d 403, 406-07 (2d Cir. 1962) (order denying third-party plaintiff's motion to proceed with trial of its claim held final).

${ }^{10}$ Radio Station WOW, Inc. v. Johnson, 326 U.S. 120, 124 (1945). Here the defendant appealed from a judgment of the state supreme court which reversed the trial court and directed that a lease and license previously transferred to the defendant for the operation of a radio station be set aside. The judgment further directed that an accounting of the defendant's operation of the radio station be made by the trial court and a decree entered accordingly. Before the accounting was completed, the defendant petitioned to the U.S. Supreme Court for a writ of certiorari, contending that only the Federal Communications Commission and the federal courts, and not the state courts, had jurisdiction over the subject matter. The state supreme court had rejected this argument, holding that its action was not inconsistent with the Federal Communications Commission's exclusive jurisdiction to grant, transfer and annul licenses.

In denying that it had jurisdiction to review the judgment, the Supreme Court said
} 
In determining what constitutes final judgments, the federal appellate courts, in reviewing district court decisions, and the Supreme Court, in reviewing the judgments of state courts, apply the same criteria. ${ }^{11}$ These criteria have been defined by the Supreme Court in the following language: to be reviewable the judgment must be final and complete, as to the entire subject matter and all the causes of action; ${ }^{12}$ it must effectively determine the litigation on the merits, ${ }^{13}$ and not merely interlocutory or intermediate steps therein; ${ }^{14}$ and it must fully determine the rights of the parties so that nothing remains to be done by the trial court except to enter the judgment which the appellate court has directed. ${ }^{15}$

However, the courts have recognized that some flexibility is needed in order to prevent the undue harshness that would result from a rigid application of the finality rule. Therefore the rule has been made subject to certain exceptions. In Local 438, Constr. \& Gen. Laborers' Union v. S. J. Curry \& Co., ${ }^{16}$ an opinion handed

that because of the potential federal-state conflict, Congress has granted it "the power to intervene in State litigation only after 'the highest court of a State in which a decision in the suit could be had' has rendered a 'final judgment or decree.' "Ibid.

${ }^{11}$ Although appellate jurisdiction in the two instances is derived from different statutory sources, see note 1 supra, the cases do not appear to distinguish between the judgments of state courts and those of federal district courts in determining whether such judgments are final. See, e.g., the language used by the Supreme Court in the following cases: Parr v. United States, 351 U.S. 513, 518 (1956); Gospel Army v. Los Angeles, 331 U.S. 543, 546 (1947); Market St. Ry. v. Railroad Comm'n, 324 U.S. 548, 551 (1945); R.H. Arnold Co. v. Guimarin \& Co., 263 U.S. 427, 434 (1923). Moreover, the courts cite state and federal cases interchangeably. See, e.g., Brown Shoe Co. v. United States, 370 U.S. 294, 306 (1962). In Ex parte Tiffany, 252 U.S. 32, 36 (1920), the Court, speaking of the terms later used in 28 U.S.C. $\$ \$ 1257,1291$ (1958), said that "final decisions" means the same thing as "final judgments and decrees."

${ }^{22}$ R.H. Anold Co. v. Guimarin \& Co., 263 U.S. 427, 434 (1923) (federal court of appeals decision affirming merits but remanding case for jury determination of damages held not final).

But see FED. R. Crv. P. 54 (b) which provides for entry of a final judgment upon one or more but less than all the claims in a multiple claim action, thus making such judgment appealable.

${ }_{13}$ Parr v. United States, 351 U.S. 513, 518 (1956) (federal district court decision granting motion to dismiss held not final).

14 Market St. Ry. v. Railroad Comm'n, 324 U.S. 548, 551 (1945) (state court judg. ment affirming order of state commission held final).

${ }^{25}$ Gospel Army v. Los Angeles, 331 U.S. 543, 546 (1947) (state court juelgment remanding case for new trial held not final).

${ }^{16} 371$ U.S. 542 (1963). Here an employer, in a state court action against a union, sought injunctive relief against picketing. The lower court refused temporary injunctive relief but the state supreme court held that the union's picketing violated a state right-to-work statute and that the lower court erred in refusing the temporary injunction. In reaching its decision, the state supreme court resolved the merits of the case when it determined that the union's picketing was unlawful. The U.S. Supreme Court granted certiorari to consider the union's claim that the subject matter of the suit, that is, the union's right to picket, was within the exclusive jurisdiction 
down on the same day as the National Bank case, the Court discussed at length two of these exceptions, utilizing them as alternative grounds for appellate review of a state court judgment. One is the collateral order doctrine under which a judgment is reviewable if it does not contain an ingredient of the cause of action but instead finally disposes of some collateral question which will not be merged in the final judgment. ${ }^{17}$ This exception was firmly established in the leading case of Cohen $v$. Beneficial Industrial Loan Corp. ${ }^{18}$ which held final a district court decision exempting plaintiffs in a stockholder's derivative suit from filing a security bond as required by state statute. There the Court said the judgment was appealable because it

did not make any step toward final disposition of the merits of the case and will not be merged in final judgment. When that time comes, it will be too late effectively to review the present order, and the rights conferred by the statute, if it is applicable, will have been lost, probably irreparably. ${ }^{19}$

The other exception arises where disposition of the collateral question resolves and thus ends, for all practical purposes, the liti-

of the National Labor Relations Board. First, however, it was necessary for the Court to consider whether it had jurisdiction over the state court's judgment with respect to finality. In its argument before the Court, the union conceded that there was nothing more of substance to be decided by the trial court. From these facts, the Supreme Court held that the state supreme court judgment was final for purposes of appeal.

${ }^{17}$ See generally 6 MOORE 9 54.14; Note, 75 HARv. L. REv. 351, 364-67 (1961); Comment, 51 Nw. U.L. REv. 746, 748-51, 757-58 (1957). In Curry, Justice Harlan concurred in the result but denied that the collateral order doctrine was applicable. He cited Montgomery Bldg. \&: Const. Trades Council v. Ledbetter Erection Co., 344 U.S. 178 (1952), where appeal was made from a state supreme court decision upholding denial of a motion to dissolve a temporary injunction against picketing. In that case the Supreme Court said the decision was not a final judgment and the fact that the question might be mooted and the picketing frustrated while awaiting the final outcome of the action on the merits did not give the interlocutory judgment the aspect of finality required.

Had Curry and Ledbetter arisen in the federal district court there would have been no problem in appealing the interlocutory judgment to the court of appeals for 28 U.S.C. $\$ 1292$ (1958), states that, "courts of appeals shall have jurisdiction of appeals from: (1) Interlocutory orders of the district courts . . granting, continuing, modifying, refusing or dissolving injunctions, or refusing to dissolve or modify injunctions, except where a direct review may be had in the Supreme Court ...."

18337 U.S. 541 (1949).

${ }^{10} \mathrm{Id}$. at 546. Accord, Swift \& Co. Packers v. Compania Colombiana Del Caribe, 339 U.S. 684 (1949) (district court's order vacating an attachment held reviewable).

In Cohen, though the Court distinguished the factual situation as one falling within the collateral order doctrine, it acknowledged the validity of the final judgment rule, noting that 28 U.S.C. $\$ 1291$ (1958) does not permit appeals, "even from fully consummated decisions, where they are but steps towards final judgment in which they will merge." 337 U.S. at 546. 
gation on the merits. In the Curry case the state supreme court resolved the merits of the entire action in reaching its decision on the interlocutory issue whether a temporary injunction against picketing should be granted. The petitioner, asserting the right to picket, conceded before the Supreme Court that he had no further defenses to offer the trial court on the merits. ${ }^{20}$ Since there was nothing more of substance to be litigated, the Supreme Court held the judgment was final.21

The apparent effect of the National Bank case is to create a new exception to the final judgment rule where the judgment involves a substantial but independent matter, anterior to the merits, where otherwise long and complex litigation on the merits may be for naught. The decision cannot be justified under existing exceptions to the rule. It does not fit within the collateral order doctrine because the state court's judgment as to venue will later be merged in the final judgment on the merits and will cause no irreparable injury in the meantime. Nor is it a situation, as in the Curry case, where disposition of the collateral question resolved the merits of the action. Moreover the facts of the case suggest that there were good reasons, not for a relaxation of the finality requirement, but for a determination that the judgment was merely interlocutory. ${ }^{22}$ And, as Justice Harlan pointed out in his dissent, ${ }^{23}$ the Court has previously decided that a determination as to venue is not "final." In Cincinnati St. Ry. v. Snell, ${ }^{24}$ the plaintiff's motion for a change

\footnotetext{
${ }^{20}$ See note 16 supra.

${ }^{21} 371$ U.S. at 550-51. (Justice Harlan's concurrence was based on this exception.) Accord, Pope v. Atlantic Coast Line R.R., 345 U.S. 379 (1953).

Other judicial exceptions to the final judgment rule have been established. Onc of these, known as the Forgay-Conrad Rule, deals with decisions which, while making a partial adjudication of the cause of action, direct that there be an immediate delivery of physical property, though an accounting or some other similar matter must be completed before a final judgment can be handed down. The irreparable injury that might result to the losing parties because of the transfer of property, were they made to await the final outcome of the litigation before appealing, is the basis for this exception. Radio Station WOW, Inc. v. Johnson, 326 U.S. 120 (1945); Forgay v. Conrad, 47 U.S. (6 How.) 200 (1848). But see Republic Natural Gas Co. v. Oklahoma, 334 U.S. 62 (1947), and Catlin v. United States, 324 U.S. 229 (1945), where the judgments were held not final though the facts seemed to call for application of the Forgay-Conrad exception. See generally 6 MOoRe I54.13. For the applicability of the requirement of finality in multiple litigation, see 6 Moore 754.15 .

${ }_{22}$ As in Republic Natural Gas Co. v. Oklahoma, 334 U.S. 62 (1947), such a determination would have the effect of avoiding possible piecemeal review, review of constitutional questions which may later be mooted by trial on the merits, and unnecessary review of the decisions of state courts.

${ }_{23} 371$ U.S. at 574.

${ }^{24} 179$ U.S. 395 (1900). This case was not cited by the majority opinion in the National Bank case.
} 
of venue was ordered granted by the state supreme court after an inferior court had denied the motion. The defendant appealed, arguing that the state venue statute on which the plaintiff relied was unconstitutional. The Supreme Court refused to take jurisdiction, declaring that although the order appealed from finally adjudged the venue question, it was no different from dozens of other interlocutory orders made in the process of litigation of a suit and was therefore not final. ${ }^{25}$ Likewise, in the National Bank case, Justice Harlan pointed out that dismissal of appellants' pleas amounted to no more than denial of a motion to dismiss, "a classic example of an interlocutory ruling that is only a step towards ultimate disposition and is not in itself reviewable as a final judgment."26

It is submitted that rather than strain valid existing exceptions, the courts might better employ other mitigating devices where they consider it desirable to alleviate the strictness of the final judgment rule. One such device is the use of a statutory listing of trial court determinations from which immediate appeals will be allowed. ${ }^{27}$

\footnotetext{
${ }^{26}$ Id. at 397 .

"Indeed, scarcely an order is imaginable which does not finally dispose of some particular point arising in the case; but that does not justify a review of such order, until the action itself has been finally disposed of. If every order were final, which finally passes upon some motion made by one or the other of the parties to a cause, it might in some cases require a dozen writs of error to dispose finally of the case." Ibid.
}

Likewise, appeals in the federal courts have been consistently rejected where the order of the district court either granted or denied a motion to transfer a case from one district to another for venue purposes. E.g., United States v. Brown, 301 F.2d 664 (4th Cix. 1962); Crummer Co. v. Du Pont, 196 F.2d 468 (5th Cir. 1952); Clinton Foods v. United States, 188 F.2d 289 (4th Cir. 1951); Paramount Pictures, Inc. v. Rodney, 186 F.2d 111 (3d Cir.), cert. denied, 340 U.S. 953 (1951).

30371 U.S. at 572. Accord, Catlin v. United States, 324 U.S. 229 (1945). In Connell v. Duben Steel Prod., 240 F.2d 414, 417 (5th Cir. 1957), it was stated that refusal to grant a motion to dismiss based on jurisdictional and other grounds is not appealable as a final decision.

${ }^{27}$ E.g., 28 U.S.C. $\$ 1292$ (a) (1958) provides that courts of appeals shall have jurisdiction of appeals from:

“(1) Interlocutory orders of the district courts . . granting, continuing, modifying, refusing or dissolving injunctions ... (2) Interlocutory orders appointing receivers, or refusing orders to wind up receiverships ... (3) Interlocutory decrees ... determining the rights and liabilities of the parties to admiralty cases ... (4) Judgments in civil actions for patent infringement which are final except for accounting." See generally Note, 75 HARv. L. Rev, 351, 367-75 (1961). The CaL. Code Civil Proc. $\$ 963$ (2) (Deering 1953) provides that appeals inay be taken from a superior court:

"2. From an order granting a new trial or denying a motion for judgment notwithstanding the verdict, or granting or dissolving an injunction ... or appointing a receiver, or dissolving or refusing to dissolve an attachment, or changing or refusing to change the place of trial ...."

See generally Note, 50 CoLUM. L. REv. I102, I110 (1950) for a discussion of the use of statutory listings. 
Another is the vesting of trial courts with discretion to authorize review, and/or appellate courts with discretion to grant review of orders which would not otherwise satisfy the finality requirement. ${ }^{28}$ A third device is the use of discretionary writs, such as the writs of mandamus, prohibition, and certiorari which can be granted without regard to finality. ${ }^{29}$ It has been argued that the writ of mandamus may provide the "most sensible and convenient solution" to the problem. ${ }^{30}$

The National Bank case appears to overrule Cincinnati St. $R y . v$. $S n e l l$ and seriously undermine the precedential value of those federal appellate cases which have refused to review district court orders

${ }^{28}$ E.g., FED. R. Crv. P. 54 (b) authorizes a trial court to expressly direct the entry of a final judgment upon one or more but less than all of the claims in a multiple claim action if it first makes an express determination that there is no just reason for delay. See generally, 6 MOORE I 54.27; Note, 75 HARv. L. REv. 351, 357.59 (1961).

28 U.S.C. § 1292 (b) (1958) provides for appellate review in federal civil cases of orders not otherwise appealable under section 1292 when the district judge is of the opinion that the order "involves a controlling question of law as to which there is substantial ground for difference of opinion," and that immediate appeal from the order "may materially advance the ultimate termination of the litigation." In such a case he shall state such opinion in the order, and the court of appeals may thereupon, "in its discretion, permit an appeal to be taken from such order . ..." Thus the statute provides that consent be given by both the district and appellate courts before appeal will lie. For a discussion of this "double discretionary system" see Note, 75 HARv. L. REv. 351, 378-82 (1961); 51 Nw. U.L. REv. 746, 759-60 (1957). See generally Note, 69 YaLE L.J. 333 (1959).

Both the use of the statutory listing and the vesting of trial courts with discretion to authorize review have their disadvantages. Courts have a tendency to interpret statutory listings narrowly. And, it is possible that appeals from listed interlocutory orders will be held mandatory rather than optional. In addition there will always be cases of immediate hardship which are not provided for. Vesting discretion to authorize review in the trial judge is a more flexible solution but the question exists whether he can be sufficiently objective in examining his own rulings. One judge might tend to deny review while another may be oversolicitous toward the complaining party. Furthermore, the requirements for appeal would differ from court to court. See Note, 50 CoLUm. L. REv. 1102, 1110-12 (1950).

${ }^{29}$ The All Writs Statute, 28 U.S.C. $\$ 1651$ (a) (1958), provides that "the Supreme Court and all courts established by Act of Congress may issue all writs necessary or appropriate in aid of their respective jurisdictions and agreeable to the usages and principles of law." See generally 6 MOORE II 54.10, 54.43[1]; Note, 75 HARv. L. REv. 351, 375-78; 51 Nw. U.L. Rev. 746, $751-58$ (1957); Note, 63 YALE L.J. 105 (1953).

${ }^{30}$ Note, 50 Corum. L. REv. 1102, 1113 (1950). This writ has been used in the past in state courts, despite its hazards, to secure immediate review of interlocutory rulings, including orders granting or refusing to grant a change of venue. State $e x$ rel. O'Neill v. Pyle, 204 Ind. 509, 184 N.E. 776 (1933); Borden v. Miles, 130 Kan. 808, 288 Pac. 563 (1930). Federal appellate courts have used it, though with some reluctance, Roche v. Evaporated Milk Ass'n, 319 U.S. 21 (1943), to review interlocutory rulings. In Ford Motor Co. v. Ryan, 182 F.2d 329 (2d Cir.), cert. denied, 340 U.S. 851 (1950), a petition for writ of mandamus, was used to secure review of a venue order where the court said the judgment was not final. But see Note, 75 HARv. L. REv. 351, 377-78 (1961), which questions whether mandamus will ever be used to provide discretionary review of interlocutory orders on a broad scale. 
granting or denying a change of venue. ${ }^{31}$ Since one of the reasons for adherence to the finality rule is not present in federal cases, that of minimizing federal-state conflict, then a fortiori the holding of the present case should apply to district court venue determinations. Furthermore, the Court's decision has created a state of uncertainty, not only in the area of venue determinations, but also in other areas involving independent interlocutory judgments where immediate review might avoid what would otherwise be long and complex, but futile litigation on the merits. However if the decision is only held to apply to state court judgments its application may well be limited because of the infrequency with which a question of federal procedure arises in a state court proceeding. The case may indicate a tacit reluctance on the part of the Court to deny review in a situation where it feels a federal question has been wrongly decided, even though the question is normally regarded as interlocutory and hence not immediately reviewable. Since there seems to be no doctrinal support for the decision it might be interpreted as an effort by the Court to provide for discretionary review of state court judgments which are not otherwise appealable, as has been done in the federal system under 28 U.S.C. $\$ 1292$ (b) (1958). ${ }^{32}$ In the National Bank case the state supreme court thought the judgment should be reviewed; review made sense to the U.S. Supreme Court; therefore it decided to take an ad hoc approach as is done under section 1292 (b), exercise its discretion, and review the decision. But, review has heretofore been considered a matter of jurisdiction and not of convenience. Whatever interpretation is given to the decision it certainly points out the need for a more extensive discussion of the finality question than was given it by the Court in the present case if means are to be found of alleviating the strictness of the final judgment rule without hampering the smooth functioning of our judicial system.

\footnotetext{
${ }^{32}$ E.g., United States v. Brown, 301 F.2d 664 (4th Cir. 1962); Crummer Co. v. Du Pont, 196 F.2d 468 (5th Cir. 1952); Clinton Foods v. United States, 188 F.2d 289 (4th Cir. 1951); Paramount Pictures, Inc. v. Rodney, 186 F.2d 111 (3rd Cir.), cert. denied, 340 U.S. 953 (1951).

${ }^{22}$ See note 28 , supra.
} 